\title{
The Anthropology and the Social Construction of Development in Post-colonial Africa
}

\author{
Wilfried Armel Mabondzo ${ }^{a}$
}

\begin{abstract}
Development is achieved neither from the vacuum nor from the abstract. It takes place in a social context and responds to specific social conditions. Many countries in Africa (especially in the sub-Saharan area) consider that the main potential contribution an agenda for socio-economic development could provide would be to put socio-anthropological studies of development back at the center of concerns. Likewise, the nature of the commitment of theorists and practitioners of yesterday and today, in a context that is described as post-colonial, especially around development projects policies, is to encourage more comprehensive and effective new approaches with regard to development in Africa. Moreover, achieving development requires also global actions to deliver on the legitimate aspiration towards further economic and social progress, requiring growth and employment, and at the same time strengthening the education system by using academic institutions, and systems to the right to make decisions about programs, quality standards, and a veriety of other educational factors.
\end{abstract}

Keywords

Anthropology, social construction, development, Africa, post-colonial

Poverty in developing countries, particularly in the rural areas of low-income countries of Asia and the Pacific, Africa, Latin America, and the Caribbean, in the least developed countries, is revealed in different ways: lack of income and productive resources sufficient to ensure sustainable livelihoods; famine; malnutrition; poor health; lack of activities or limited access to education and other basic services; increased morbidity and mortality due to diseases; lack or inadequate housing; unhealthy environment; and social discrimination and exclusion. Another important feature is that the poor hardly partake, if not rarely, in decisions in the civil, social, and cultural life. These are elements among many others that significantly affect inequality between social groups and genders, with oversized impact on demographic parameters, food insecurity, etc.
Let us remember that 70 years after the World War II, it is still not easy to talk about development (although very long rooted in the economics thoughts) without any appeal to its rise, evolution, and various theoretical approaches that have changed over time. The assessment is quite easy and is illustrated in the massive reflux extensive theoretical syntheses that marked the various mutations and ruptures of the world order during the years of 1960-1970. After a long period of open confrontation of theoretical constructs and world views, social sciences are still growing analytical trends and folding on

aUniversity of Montreal, Montreal, Canada

Correspondent Author:

Wilfried Armel Mabondzo, 208-10130, Place Meilleur, Montréal, QC, H3L 3K5, Canada 
methodological research. With the revaluation of past evidence, restrictions on various fields of investigation, reinforced by the scientific relativism have become a masterpiece in the world of social science research.

\section{LOOKING INTO THE ORIGIN OF THE CONCEPT OF DEVELOPMENT}

It is important to know that the history of the development paradigm depends on a very old and complex history, which are the Neolithic Revolution (characterized by the transition from nomadic life to the sedentary life style) and the Industrial Revolution (likely around the transition from agrarian to industrial and urban society). As a result, it is clear that the history of the development paradigm, has profoundly marked the history of humankind (Roch 2013). But as some authors point out, it is much more from the idea of economic progress that the term "development" emerged and brought about changes in lifestyles, consumption, production, and social organization (Coquery-Vidrovitch 1988; Sauvy 1952). Underdevelopment only exists in comparison with countries that have greatly improved their social and economic status.

\section{Looking in the Context of European (Re)construction}

The World War II had brought its consequences in the entire fighting European countries. It was therefore needful to rebuild the ruined Europe. The "Marshall Plan", which came to be on June 5, 1947, is rooted from that need. Its ultimate goal was to help the economy of Europe in crisis (Rist 2001) and, obviously, to overhaul the European political and economic relations, stained with all sorts of conflicts. One of the unforgettable phrases in terms of reconstruction development economics, is that of President Truman, said (in January 1949) during his inauguration speech for highest position in United States:
(...) we need to launch a program that is bold and puts the benefits of our scientific advances and industrial progress of our service improvement and growth of underdeveloped areas. Their poverty is indeed a handicap and a threat both to them and to the more prosperous regions. (...) Only democracy can provide the life-giving force that will mobilize people for action which will enable them to overcome not only their oppressors but also their eternal enemies: hunger, misery, despair. (Rist 2001)

This speech inaugurates the era of "development".

Considered as a new paradigm (concept), development in its economic sense, is related to greater awareness of economic backwardness for countries of the "Third World" (Sauvy 1952). This is an independent political subject, bearer of common interests not only with relation to the former metropolises, but also in contrast with the two blocks that divided the world after the Yalta agreements: The third world converges with non-alignment, as evidenced by the work carried out before, during and after the Afro-Asian Bandung conference in 1955, around a few such great liberators as Nehru, Nasser, Sukarno, and Zhou Enlai (Rist 1997; Bessis 2002; Treillet 2005). India, Indonesia, Egypt, and Vietnam show the way for national independence. The Africans (French and English) will follow Vietnam a few years later. Algerian and Portuguese's African, finally, will wrest their independence out of arms.

\section{Facing the Socio-economic Situation in Africa}

From the first years of the 1960s on, many states access national sovereignty, accompanied by a music which will earn the unprecedented visit, such as "Independence Cha-Cha" of "African Jazz Group" of Joseph Kabasselé. During the same transitional period, they accept a constitution granted by the local Legislative Assembly under the Metropolitan Constitution (where autonomous states of the community are defined by the Constitution of the French Republic in 1958). In this first phase, the Parliament appears particularly as an excellent system of decolonization in Africa. This is to set up 
government structures and also to entrust the representatives of a majority consisting, according to each case, of a coalition of several parties or of a dominant party, even though sometimes the only party remained in the political race (Conac 1990).

It should be remembered that that time also corresponds with the time of the adoption of mono-partisan regimes in several countries with what it entails as restriction of civil liberties and the quest for economic stability (Abega 2007). To achieve this, two main systems will be tested: fact and law. In this phase of state-building and economic start, it was essential that the modernist elites were gathered around common goals and protected infant industries (still fragile) against competition on the world stage. African countries will experience a problem they will all face, namely socio-economic crisis. Most will realize this and a number of political strategies will be utilized to overcome their economic weakness, the main aim being that of improving the living conditions of the population, the fight against poverty, insecurity food, privatization of all kinds, and as many social and economic crises (Friedmann and Sandercock 1995; Nouguerede 1990).

Africa is therefore deemed a continent under construction. Many projects are funded with billions and economic development is conceived in terms of quantity, or to use one of the most well-known expressions of the Burkinabe's historian Ki Zerbo, one is in the presence of an "all-inclusive development" (1992). The real interest at the time for African governments is more engineers and technicians to put the first projects developed by experts from international organizations (World Bank, International Monetary Fund, etc.) into practice. Unfortunately, overconfidence, social marginalization of populations, the lack of analytical capacity, and sometimes the ethical failure on the part of the funded governments (400 billion as donations and loans ${ }^{1}$, in 30 years) explain the burden of African debt.

\section{DEVELOPMENT AND SOCIO-ANTHROPOLOGICAL APPROACHES}

Development, but also the history of social sciences that accompany it for over half a century, was probably at the height of a particular mobilization of writings and publications disciplinary, interdisciplinary, and multidisciplinary, bringing together around a same project, most of eminent scientists from different horizons, researchers such as anthropologists, sociologists, political scientists, geographers, psychologists, demographers, historians, lawyers, and especially, and of course, economists, were to speak only of the humanities, and without mentioning the two twinning close disciplines: the anthropology of development, taught in universities, colleges, and social research centers. No matter the diversity of engaged fields in the research and their method, it remains subject to the study of a project and/or the same reality, that is development, which it shares with other theorists and researchers, and requires, at least, as careful and relevant a reflection, as well as in substance and in form (Lombard 1992).

\section{The Equation of}

\section{"Anthropology-of-Development"}

Clear as it is, the development issue was the focus of grassroots specialists (researchers), the French school of economic anthropology was in particular characterized by the existence of a tradition of political engagement, assimilationist, the eyes of the colonial administration in search of cultural heritage (Balandier 1963; Leclerc 1972). The strong involvement of their anthropological work in the political and economic field through the theorization of the articulation of modes of production (Meillassoux 1992; Rey 1991), lead, moreover, to open a debate on the various policy implications of the anthropology, social transformations from the colonial period, the postulates of economic theories of social 
development, and the level of commitment anthropologists will agitate the profession until the mid-1970s (Copans 1974; Dumont 1991).

In the early 1980s, the ideology of development, according to its priorities or specificities, differed considerably depending on countries, (sub)-regional areas, and societies. There is development only where there are developers such as: public institutions (state, international) or parastatal organizations (the various organizations of civil society) with the ultimate function: the social and economic development (Bare 1995). Far from being neutral, development anthropology will cause the questioning of the discourse and practice of development, putting forward, according to a vision downright poststructuralist ${ }^{2}$, interactions between developing or developed local and state actors (Olivier de Sardan 1995). The question is therefore not so much to provide new perspectives to better development, but to consider the foundation on which the social and economic development is constituted as an object of thought, of anthropological and social practice knowledge.

The other major center for the development of anthropology is that it must analyze the programs of action and intervention as cultural works (Albert 1995), while preserving its critical status of science to study the political, social, and economic issues (including development) of populations, as well as “(...) the old anthropology analyzed the kinship systems, political and economic institutions, spontaneous process of change, exactly the same methods and the same technical approaches" (Bastide 1971; Amin 1993; Wolf 1982). As Chauveau (1984) said, development discourse, the form in which it develops its arguments and establishes its authority, concerns "(1) induced changes (...) which are only a particular form of social change; (2) the effects of these interventions (...) mediated by a series of other social change modalities".

\section{The Equation of "Anthropology-of-Change-Social"}

Long considered precursors Malinowski, Radcliffe-Brown, Evans-Pritchard were among those who debated whether anthropology should be practically involved in the promotion of social change or not. For Malinowski (1929), cultural change is an essential aspect of anthropological research and it gives the notion of "culture" a much broader sense than the majority of British anthropologists. Culture encompasses all social phenomena. It is an organic unity. Radcliffe-Brown (1930) attributed a reducing use of the term social structure, based on the fact that companies maintain over time stability. Therefore, social change no longer appears as a clearly destructive factor, but as a constructive factor of social reality. Thanks to the contribution of Evans-Pritchard (1946), anthropology that invests in business practices is no longer working in the anthropological field, but within the non-scientific field of administration (Hagberg 2007).

Let us say the aforementioned three authors who share sensitivity to socio-economic change, the evolution of society, but also the role of anthropology in social interactions. Their various quantitative and qualitative approaches, tied to social and cultural stratification of populations surveyed, are inspired by following the positions of certain developmentalist. Many theorists reflect the progress of the anthropology of social change (Olivier de Sardan 1995; Escobar 1997; Hoben 1982), an anthropology within the meaning of Cernea $(1985 ;$ 1995) associated with development. This anthropology is called dynamistic anthropology and it is promoted by Balandier (1963), as opposed to an anthropology which, to be "structural", would be static and conservative (Levi-Strauss 1952; 1958).

Taking the social organization as a framework, reflected by Cernea (1998), it is imperative that the development analysis is centered on social actors. This 
comes from the explanatory and prescriptive functions of applied research. The role of most practitioners of anthropology associated with the development is not confined to any particular area. But rather, it shows that these are capable of providing enough detailed analyses of social organization in which projects are joined and of underlying actions of the local population, which connects them with applied research (Cernea 1997). In doing so, they become partners in designing and implementing projects (Horowitz 1994; Escobar 1997). The "practice" of anthropology is an added value to society if it embodies social change.

Based on the critical reading on the subject, we can say that the position taken by Cernea and his peers is not totally unanimous. This especially as practitioners do not bother to see the overall development needs, but still accept as a given rendering accurately reflecting social reality. Although Cernea and his peers are recognizable through a "realist epistemology", development experts as well as supporters of academic anthropology-mainly for moral and intellectual reasons-view them as nuisances or incurable dreamers, carried away by a "dogmatic slumber" (Gow 1993; Grillo 1985). Such weakness would prevent them from engaging resolutely to tell truth to power, nationally and internationally, for fear of being discredited.

\section{DEVELOPMENT: A CHALLENGE FOR AFRICAN RESEARCHERS}

More than half a century after the first African independence, the major issues formerly addressed (poverty, underdevelopment, human rights ...) in the colonial or post-colonial context are certainly remained valid, but have rather been redesigned and rested in the context of today, that of globalization. The transformations that have occurred over the years have followed more logic adapted to social and economic policies of each country. The literature on multiple African development studies, calling mainly to the contributions of African theorists is quite diverse. It focuses on the theoretical and empirical aspects that characterize the structure of African societies, despite their many differences. Among the analysis including: the production status of African social science in a sociopolitical context convalescent state and nature of their involvement in the development and social change in Africa.

\section{The Post-colonial Context of the Social Sciences in Africa}

For African theorists, if the search logic has been in the spotlight before the logics of action, it is precisely because they wanted to mark by this (at least most of them), social science research in Africa is one of the forms of action influenced by the Marxist approach in asking some places to "disconnect" outright countries belonging to a district dominated and exploited by northern countries. This is also in this spirit of ideas that we can use the work of Samir Amin (1989; 1985; 2005), becoming the standard real harbor inequalities of the international division of labor and the dependence of the country South in general and Africa in particular. For main theoretician of anti-globalization, it promotes a way of developing African countries in the Marxist way as an extension to the Third World for his years saying Maoist (Abe 2007).

In Cameroon, to take this case as study, the inordinate development of rural communities and the various problems that beset, of the same order as in the countries of the CEMAC (Economic and Monetary Community of Central Africa), and appear at the height of the thought of J. M. Ela, recognized as a philosopher, theologian, sociologist, and anthropologist. Many years of field work with marginalized populations by public authorities (the only time !!!?) allow him to enter "the cry of the African man" (1980) to the inside and outside "the villages of Africa" (1982). Through his many publications, the author proposes to "reconstruct the 
history of African societies" (1994) through a new practice of social sciences which he considers a "contemporary ethnology". Far from making Africa an outright place of training or initiation where international institutions are forging working tools to investigate the modes of being and types of organization of Western societies, J. M. Ela (1994) rather attracted the attention of African intellectual elites on the redefinition of the function of social science given the changes that are emerging in the current research field. For a long time left on their own, they would wither away into oblivion. Faculties of Humanities at the Marien Ngouabi University, confine the communication among sciences, philosophy, anthropology, sociology, demographics, geography, history, etc.

This is the situation, more or less showy, in which a great number of African researchers who, having neither defined nor defended, cannot play the role that society is entitled to expect of them. African development is thought from social realities and paradigms that do not have too much compared with the conditions in which people live their daily lives. The effects of extraversion literacy in the studies and analyses on issues that affect African societies do not play in their favor. The West is still there, as omnipresent Father, omnipotent, omniscient, in the mind of the intellectual elite and the African researcher (Buakasa 1996; Mwabila 1980), the scientific dimension of his work is guaranteed, in the eyes of the scientific opinion by major universities and western schools. As evidenced by Mudimbe (1980), “(...) the order of things as models of all scientific practice patterns are developed in the West. The social sciences are often in Africa, images and expressions of a discreet but effective power of good students trained in the school of whites update". The same idea is found in the works of many African researchers who, having been marked by post-colonial misery, probed the dependency relationships that unite the West Africa (Diop 1987; Diouf 1993).

\section{The Formulation of the Commitment of African Researchers}

Whatever we say or whatever we do, we cannot forget the indisputable element that, African social science is a product of Western modernity (Copans 2010). But it is part of a bypass position relative to a unique African philosophical inspiration (Hountondji 1977; Mudimbe 1980; Mbembe 2000). Now, the "authenticity" of black African identity, noting Eboussi Boulaga (2002), is one of the Africans determined to exist, in other words, one that allows the Muntu (the African person) to consider himself or herself responsible for his/her past condition, not because he gives or represents them, but they are his. Here you can let marvel at a rewarding substance that comes from the Hegelian dialectic. It consists of defining the identity not as something already given, as a destiny, but what determines dialectically, in a given process of negation and self-affirmation through this negation (Mbonda 2009). It is in this conception of the identity or the African culture, an ethno-anthropological and philosophical heritage of the African type, focuses on essential existential implications: rather than being entertained by data from elsewhere, the African intellectual has to concentrate on his own process to become human.

From this flow, the idea takes one hand out of the "underdevelopment" of the social sciences in Africa and, secondly, is to empower African researchers in knowledge production from the realities sociocultural environment in the (Abe 2007) which they are practiced (Diouf 1993; Bongeli 2001). The "awareness" of intellectuals and African researchers is necessary and appropriate from a few fields of application determined by the major challenges of an Africa in crisis (Ela 1994), but also in perpetual social and cultural change. Hence, the need is for "dynamic" approach to the analysis fields that make modern Africa a veritable laboratory of social sciences. Everything is also about changing attitudes. This is to 
change the African man so that he becomes able to look to a future from its cultural environment.

\section{CONCLUSIONS}

Reflecting today on the development of anthropology in Africa, it is also lingering in the human being that we cannot impose a form or a human mold; nor one to whom we can learn to be human. That is to say, the role of the social environment that surrounds him is to allow him to develop his own potential and not necessarily, a more or less explicit and sustained manner the potentialities of its environment (Maslow 1968). Its potential and capabilities are not given to him, de facto, by the environment; it possesses in embryonic and imperfect form, such as arms, legs, feet, or eyes. Creativity, good sense, spontaneity, discerning of spirits, the production of knowledge, openness, attention to others, the desire for truth, the realization of his existential project, the ability to help others, different from him, but sometimes sober state, etc., are listed embryonically potential in him, but, particularly, are an integral part, as well as the brain, arms, teeth, legs, or eyes of his body. This combination of different elements defines the other within their social environment.

Human being is also a system which needs to live in a well-organized and stable social environment. Based on this element, we cannot finally put aside many facts which clearly show that it is absolutely essential to have a family and a culture to realize its potential and capabilities, characteristics of what is specifically human. Finally, the idea of accompanying the human in a socio-economic development process is not new. In fact, it is inherent in the human adventure and human destiny. With this in mind, we can say that human being, whatever he/she is and wherever he/she is, is simultaneously what he/she is and what he/she aspires to be. Human is conceived today as a perfect identity than as a "player-perfect" social body which is identified. One can almost say that human is not produced by a society and its institutions, but he/she is the product of himself/herself, as well as integrated "product" in an unpublished societal context, that many countries in sub-Saharan Africa by example, are marked throughout their history, by economic and social changes.

As the unveiling embodied consciousness of a being, that is to say, what it is and actually has a specific mode of existence, the being human appears simultaneously as the point of origin and emergence of a humanist anthropology capable - among other things - to think about the human condition and, thereby, promote social and economic "development", which is articulated in a kind of relationship between himself and his/her environment. That is to say, the anthropologist should be, in our humble opinion, that person who from his/her discerning listening, adjusted his/her speech, his/her counseling (but the aid proposed here is rather that of a travel companion than the expert who knows it all), and his/her observant participation and participant observation in the field, allowing the population together (in various development projects and programs) to become what it is called to be, particularly in connection with its socio-cultural values. The concept of humanistic anthropology should induce developing countries (in Africa) to a kind of directivity and control over the human fate and respect for a subject who wants to become fully responsible for his existential work.

\section{Acknowledgements}

The author would like to thank M. Mouck-Mahoukou Teddy for his helpful comments on drafts of this paper and also for his language correction.

\section{Notes}

1. The issue of public external debt of African countries has been written (and continues to run) of the ink from social scientists. Several analyses - and critics - remain on the 
issue. Despite having contributed to the economic momentum in some countries (South Africa, for example), there are many who believe that public debt in Africa is at the center of a social tragedy, a direct consequence of geopolitical choices in both powerful countries of the South and instrument of domination and a formidable mechanism for transferring wealth of peoples to Northern creditors.

2. Contrary to liberal theories based on the individual (driver of the company) and the market, and different theories of Marxist economic anthropology, based on economic output and constituting a major landmark in the (re)-assessment the gains of the $1970 \mathrm{~s}$, post-structuralism emphasizes the role of language and meaning in the constitution of social reality. For Escobar (1997), language and speech are considered not as a reflection of social reality, but as constitutive of that reality. It is through language and discourse that social reality inevitably arises. The discourse paradigm allows specialists of "development" to transcend the binary vision integral to much of social theory, and between the ideal and the real, the symbolic and the material, production and meaning, since the speech encompasses it all.

\section{References}

Abe, C. 2001. L'Afrique à l'épreuve de la mondialisation (Africa to the Test of Globalization). Yaoundé: Cahiers de l'UCAC.

- 2007. "Cours inédit de sociologie du développement" (Unpublished Courses of Sociology of Development). Masters I-II: Développement et management des projets en Afrique, Université Catholique d'Afrique Centrale (Master degrees I-II: Development and Mamangement of Projects in Africa; Catholic University of Central Africa), 2006-2007.

Abega, S.-C. 2007. Le retour de la sociétécivile en Afrique (The Return of Civil Society in Africa). Yaoundé: Presses de l'UCAC.

Albert, B. 1995. "Anthropologie appliquée ou anthropologie impliquée? Ethnographie, minorités et développement" (Applied Anthropology or Anthropology Involved? Ethnography, Minorities and Development). In Les applications de l'anthropologie. Un essai de réflexion collective depuis la France (The Applications of Anthropology. A Test of Collective Reflection From France), edited by J.-F. Bare. Paris: Karthala.

Amin, S. 1985. La déconnexion: Pour sortir du système mondial (The Disconnection: To Exit the Global System). Paris: La Découverte.

1989. La faillite du développement en Afrique et dans le tiers monde (The Failure of Development in African and in the Third World). Paris: L'Harmattan.

_. 1993. Itinéraire intellectuel: regards sur le démi-siècle 1945-1990 (Intellectual Itinerary: Glances on the Half-Century 1945-1990). Paris: L'Harmattan.

—. 2005. L'Afrique: Exclusion programméeou renaissance (Africa: Programmed Exclusion or Rebirth)? Paris: Maisonneuve.

Balandier, G. 1963. Sociologie actuelle de l'Afrique Noire (Current Sociology of Black Africa). Paris: PUF.

Bare, J.-F. 1995. "En quoi peut bien consister une anthropologie appliquée au développement" (In What Can Consist Well the Applied Anthropology to Development)? In Les applications de l'anthropologie. Un essai de réflexion collective depuis la France (The Applications of Anthropology. A Test of Collective Reflection From France). Paris: Karthala.

Bastide, R. 1971. Anthropologie appliquée (Applied Anthropology). Paris: Payot.

Bessis, S. 2002. L'Occident et les autres. Histoire d'une suprématie (Occident and Others. History of a Supremacy). Paris: La Découverte.

Bongeli, E. 2001. Sociologie et Sociologues africains. Pour une recherche sociale citoyenne au Congo-Kinshasa (African Sociology and Sociologists. For a Social Research Citizen in Congo-Kinshasa). Paris: L'Harmattan.

Buakasa, G. 1996. Réinventer l'Afrique sur l'axe de sa tradition. Application au cas du Congo-Zaïre (Reinventing Africa on the Axis of Its Tradition. Application to the Case of Congo-Zaire). Paris: L'Harmattan.

Cernea, M. 1985. Putting People First. New York: Oxford University Press.

— 1995. Social Organization and Development Anthropology. In Malinowsky Award Lecture, Society for Applied Anthropology. Washington, D.C.: Banquemondiale.

- 1997. Social Assessment for Better Development: Case Studies in Russia and Central Asia. Washington, D.C.: World Bank.

- 1998. La dimension humaine dans les projets de développement. Les variables sociologiques et culturelles (The Human Dimension in the Development Projects. Sociological and Cultural Variables). Paris: Karthala.

Chauveau, J.-P. 1984. "Le développement approprié. Mise en valeur coloniale et autonomie locale: Perspective historique sur deux exemples ouest-africains" (The Appropriate Development. Enhancement of Colonial Value and Local Autonomy: Historical Perspective on Two West African Examples). In Histoire, Histoires (History, Stories). Paris: ORS-TOM.

Conac, G. 1990. "Le processus de démocratisation en Afrique" (The Democratization Process in Africa). In L'Afrique en 
transition vers le pluralisme politique (Africa in Transition Towards Political Pluralism), edited by G. Conac. Paris: Economica.

Copans, J. 1974. Critiques etpolitiques de l'anthropologie (Critics and Policies of Anthropology). Paris: Maspero.

- 2010. Un demi-siècle d'africanisme africain. Terrains, acteurs et enjeux des sciences sociales en Afrique indépendante (One Half-Century of African Africanism. Fields, Actors and Issues of Social Sciences in Independent Africa). Paris: Karthala.

Coquery-Vidrovitch, C. 1988. Pour une histoire $d u$ développement: États, sociétés, développement (For a History of Development: States, Societies, Development). Paris: L'Harmattan.

Diop, C.-A. 1987. L'Afrique noire précoloniale: étude comparée des systèmes politiques et sociaux de l'Europe et de l'Amérique noire, de l'Antiquité à la formation des étatsmodernes (The Pre-colonial Black Africa: Comparative Study of Political and Social Systems of Europe and of Black America, From Antiquity to the Formation of Modern States). Paris: Présenceafricaine.

Diouf, M. 1993. "Les intellectuels africains face à l'entreprise démocratique: entre citoyenneté et expertise" (The African Intellectuals Against the Democratic Enterprise: Between Citizenship and Expertise). Politique africaine, no. 51, Intellectuels africains, Octobre (African Politics, no. 51 African Intellectuals, October).

Dumont, L. 1991. Essais sur l'individualisme: une perspective anthropologique sur l'idéologie moderne (Essays on Individualism: An Anthropological Perspective on Modern Ideology). Paris: Seuil.

Eboussi Boulaga, F. 1977. La crise du Muntu (The Crisis of Muntu). Paris: Présenceafricaine.

—. 2002. "L'identité négro-africaine" (The Black African Identity), Présence africaine (African Presence), numéro thématique Penser l'Afrique au XXe siècle: une anthologie, no. 165-166 (Special Issue on Think Africa in the Twentieth Century: An Anthology, no. 165-166).

Ela, J.-M. 1980. Le cri de l'hommeafricain (The Cry of African Man). Paris: L'Harmattan.

_. 1982. L'Afrique des villages (Africa of the Villages). Paris: Karthala.

—. 1994. Restituer l'histoire aux sociétés africaines. Promouvoir les sciences sociales en Afrique noire (Restore the History of African Societies. Promote Social Sciences in Black African Area). Paris: L'Harmattan.

Escobar, A. 1997. "Anthropologie et développement" (Anthropology and Development). Revue internationale des sciences sociales (International Review of Social Sciences), no. 154, Déc (December).

Evans-Pritchard, E.-E. 1946. "Applied Anthropology.” Africa, no. 16, February, pp. 92-98.

Friedmann, J. 1995. Les dépossédés, Le Courrier de l'UNESCO, Le développement pour qui? Mars (The Dispossessed, The UNESCO Mail, Development for Whom? March).

Gow, D., 1993. "Doubly Damned: Dealing With Power and Praxis in Development Anthropology." Human Organization, no. 52, April, pp. 380-397.

Grillo, R. 1985. "Applied Anthropology in the 1980s: Retrospect and Prospect." Pp. 1-36 in Social Anthropology and Development Policy, edited by R. Grillo and A. Rew. Londres: Tavistock Publications.

Hagberg, S. 2007. "Comprendre sans légitimer" (Understand Without Legitimazing). In Une anthropologie entre rigueur et engagement. Essais autour de l'œuvre de Jean-Pierre Olivier de Sardan (An Anthropology Between Rigour and Commitment. Essays Around the Work of Jean-Pierre Olivier de Sardan), edited by T. Bierschenk. Paris: Karthala.

Hoben, A. 1982. "Anthropologists and Development." Annual Review of Anthropology 11(12):349-375.

Horowitz, M. 1994. "Development Anthropology in the Mid-1990s." Development Anthropology Network 12(1 \& 2):1-14.

Hountondji, P. 1977. Sur la philosophie africaine: critique de l'ethnophilosophie (On African Philosophy: Criticism of Ethonophilosophy). Paris: Masparo.

Ki-Zerbo, J. 1992. La natte des autres. Pour un développement endogène en Afrique (The Mat of the Others. For an Endogenous Development in Africa). Dakar: CODESRIA.

Leclerc, G. 1972. Anthropologie et colonialisme: essai sur l'histoire de l'africanisme (Anthropology and Colonialism: An Essay on the History of Africanism). Paris: Fayard.

Levi-Strauss, C. 1952. Race et histoire (Race and History). Paris: Gallimard.

- 1958. Anthropologie structurale (Structural Anthropology). Paris: Plon.

Lombard, J. 1992. Une sociologie à la recherche de son identité Esquisse d'un bilan (A Sociology in Search of Its Identity. Draft on an Assessment). In L'année sociologique (The Sociological Year), vol. 42, pp. 87-138.

Malinowski, B. 1929. "Practical Anthropology." Africa, no. 2, janvier (January), pp. 22-38.

Maslow, A. 1968. Vers une psychologie de l'Etre (Toward a Psychology of Being). Paris: Fayard.

Mbembe, A. 2000. De la postcolonie (The Post-colony). Paris: Karthala.

Mbonda, E.-M. 2009. "La révolution afrocentriste" (The Afrocentrist Revolution). In KOM, Fabien Eboussi Boulaga, la philosophie du Muntu (Fabien Eboussi Boulaga, the Philosophy of Muntu). Paris: Karthala. 
Meillassoux, C. 1992. Femmes, greniers et capitaux (Women, Attics and Capital). Paris: L'Harmattan.

Mudimbe, V.-Y. 1980. "La culture" (The Culture), In Du Congo au Zaïre: 1960-1980 (Congo au Zaïre: 1960-1980), edited by A. Huybrechts and B. Verhaegen. Essai de bilan, Bruxelles: CRISP.

Mwabila, M. C. 1980. "Pour une relecture de la sociologie à la lumière de la théorie de la dépendance" (For a Second Reading of Sociology in the Light of the Theory of the Dependence). In La dépendance de l'Afrique et les moyens d'y remédier (The Dependency of Africa and the Ways to Remedy Them). Actes de la $4^{\mathrm{e}}$ session du Congrès International des étudesafricaines, Kinshasa, 12-16 décembre, 1978 (Acts of the 4th Session of the International Congress of the African Studies, Kinshasa, December 12-16, 1978), pp. 263-264.

Nouguerede, Y. 1990. "Coopération internationale, démocratie et développement" (International Cooperation, Democraty and Development). In L'Afrique en transition vers le pluralisme politique (Africa of Transition Towards Political Pluralism), edited by G. Conac. Paris: Economica.

Olivier de Sardan, J.-P. 1995. Anthropologie et développement. Essai en socio-anthropologie du changement social (Anthropology and Development. Essay in Socioanthropology of the Social Change). Paris: Karthala.

Radcliffe-Brown, A.-R. 1930. Applied Anthropology. Research in Economic Anthropology. No. 3, pp. 123-134.

Rey, P.-P. 1991. "L'anthropologue et l'engagement: de la politique à la pratique" (Anthropologist and Commitment:
From Policy to Practice). Cahier du GEMDEV (Workbook of GEMDEV), no. 8, juin (June).

Rist, G. 1997. The History of Development: From Western Origins to Global Faith. London and New York: Zed Books.

- 2001. Le développement. Histoire d'une croyance occidentale (Development. History on a Western Belief). Paris: Presses de sciences Po.

Roch, F. 2013. Vers un nouveau paradigme en matière de développement (Towards a New Paradigm for Development) (T. 1-2). Saarbrücken: Presses Académiques Francophones.

Rouille d'Orfeuil, H. 1997. Le tiers monde (The Third World). Paris: La Découverte.

Sauvy, A. 1952. Théorie générale de la population (The General Theory of Population). Paris: PUF.

Treillet, S. 2005. L'économie du développement. De Bandoeng à la mondialisation (The Economy of Development. From Bandoeng to Globalization). Paris: A. Colin.

Wolf, E. 1982. Europe and the People Without History. Berkeley: University of California Press.

\section{Bio}

Wilfried Armel Mabondzo, Ph.D. candidate in Anthropology, University of Montreal, Canada; research fields: food security, cultural anthropology, development and management of project, human resources management. 